\title{
Big Data in the Maritime Industry
}

\section{Veliki skupovi podataka u pomorskoj industriji}

\author{
Maris Mirović \\ Student, Department of Electrical \\ Engineering and Computing \\ University of Dubrovnik \\ e-mail:marism580@gmail.com
}

\author{
Mario Miličević \\ Department of Electrical Engineering and \\ Computing \\ University of Dubrovnik \\ e-mail: mario.milicevic@unidu.hr
}

\author{
Ines Obradović \\ Department of Electrical Engineering and \\ Computing \\ University of Dubrovnik \\ e-mail: ines.obradovic@unidu.hr
}

DOI 10.17818/NM/2018/1.8

UDK 656.61

Review / Pregledni rad

Paper accepted / Rukopis primljen: 5. 7. 2017.

\begin{abstract}
Summary
Maritime industry is a complex system that requires a quick adaptation to changing conditions and in which decision-making needs to take into account a large number of parameters. As navigation systems become more advanced, there is a significant amount of ship performance and navigation data generated. Big Data analytics tools make it possible to analyze these large quantities of data in order to gain the insight that supports decision-making. This paper gives an overview of the applications of Big Data in maritime industry, specifically in logistics optimization, safety and energy efficiency improvement, as well as the challenges that systems involving Big Data face.
\end{abstract}

\section{Sažetak}

Pomorska industrija je složeni sustav koji zahtijeva brzu prilagodbu u promjenjivim uvjetima u kojima je potrebno uzeti u obzir velik broj parametara prilikom donošenja odluka. Napretkom navigacijskih sustava, generira se znatna količina podataka o performansama broda i navigaciji. Analitički alati za velike skupove podataka omogućuju analizu tih podataka kako bi se dobilo razumijevanje potrebno za podršku donošenju odlukâ. Ovaj članak daje pregled primjene velikih skupova podataka u pomorstvu, posebno u optimizaciji logistike, sigurnosti i poboljšanju energetske učinkovitosti, kao i izazove s kojima se suočavaju sustavi koji koriste velike skupove podataka.

\section{KEY WORDS}

maritime industry

big data

logistic optimization

energy efficiency

safety

\section{KLJUČNE RIJEČI \\ pomorstvo \\ veliki skupovi podataka \\ optimizacija logistike \\ energetska učinkovitost \\ sigurnost}

\section{INTRODUCTION / Uvod}

Seaborne trade accounts for over 90 percent of world trade in terms of volume [13]. Due to the size of the network that maritime logistics companies operate, they face large scale planning problems at the strategic, tactical and operational level [5]. Making decisions regarding maritime logistics to ensure safety, minimize cost and improve productivity means taking into account a large number of parameters susceptible to change. This is further complicated by the limitations of shipto-shore communication, which is why the maritime industry is traditionally not information intensive.

However, with the development of navigation systems, sensors and tracking systems following recent advances in technology, the maritime industry is opening up to the benefits of the digital era. The growing amount of available data concerning ship performance and navigation brings a wide range of possibilities, from real-time monitoring of vessels to extracting knowledge through data analysis. The volume and variety of maritime data make this a Big Data problem.

The following sections explain the term Big Data and present the way Big Data can be used in logistics and transportation in general and the maritime industry in particular.

\section{THE DEFINITION OF BIG DATA / Definicija pojma velikih skupova podataka}

With the development of technology, the volume of data generated by countless systems, sensors and devices is growing rapidly. It is estimated that by 2020 the amount of digital data in the world will reach 40 trillion gigabytes [12]. The term Big Data was initially used to describe data sets so large and complex that traditional software is unable to process them [26]. Today, it is a concept that goes beyond the issue of dealing with large quantities of data. Now that Big Data analytics solutions are available, the focus has moved to the value that can be extracted. The term Big Data nowadays refers not only to the data themselves, but also to advancing trends in technology that aim to take advantage of the opportunities that such data offer, which is a new approach to understanding the world and making decisions [17].

The data involved are often described as high-volume, highvelocity and high-variety (Figure 1) [7]. While volume applies to the magnitude of data, variety entails structural heterogeneity, meaning that the data consist of various types, including unstructured data such as text, images, video and audio. Velocity, on the other hand, refers to the rate at which data are 
generated and the speed at which they should be analyzed [11]. The point at which any of these characteristics may be rated high is relative. Consequently, many definitions instead point out the requirement for specific technology and analytical methods as the main characteristic of Big Data [7]. While these qualities do present challenges when it comes to processing the data, they are also what makes the data extremely valuable. It means that, with the right analytical tools, the data can be analyzed for patterns in order to gain insight that couldn't be achieved on a smaller scale.

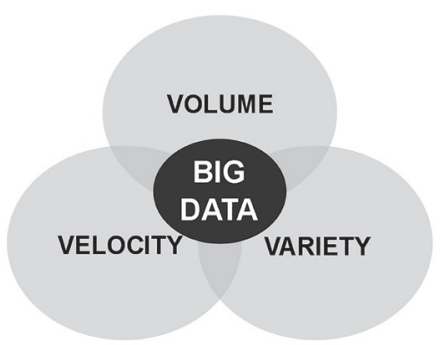

Figure 1 Big Data characteristics

Slika 1. Karakteristike velikih skupova podataka

There are many examples of Big Data being used in practice. Companies are expanding their traditional data sets with social media data, browser logs and similar data to get a better understanding of their customers, their behaviors and preferences. Retailers can optimize stock based on predictions generated from Big Data. Credit card companies use it for fraud detection. More and more cities use data from road sensors and cameras to optimize traffic flow. Delivery routes are optimized using geographic positioning and radio frequency identification sensors. Big Data is also used in medicine. For example, recording and analyzing heartbeat and breathing patterns of patients in a specialist premature and sick baby unit has enabled predicting infections 24 hours before physical symptoms appear [14]. It seems that there's no area that wouldn't benefit from the usage of Big Data. The awareness of its value and potential continues to grow.

\section{BIG DATA IN LOGISTICS AND TRANSPORTATION / Primjena velikih skupova podataka u logistici i transportu}

Big Data analytics brings many benefits to logistics and transportation industry. The data are collected from a very large network of sensors and devices. Big data analytics tools are efficient in storing the data and processing them in real time in order to monitor traffic and make predictions that improve service quality and companies' revenues [3].

Data generated by traffic sensors can be used to identify issues in real time, which means that road users can make informed decisions to save time while road authorities may control traffic and intervene quickly when needed [18], [30]. Los Angeles, for example, uses the data to control traffic lights, which has reduced traffic congestion by an estimated 16 percent [14]. In Dublin, the data collected from traffic sensors, bus GPS devices and other sources are used to build a real-time digital map of the city transportation network. It helps identify traffic problems and make decisions regarding the bus transportation network. As a result, the traffic flow in the city has been improved [3].

The private sector may gain competitive advantage and increase productivity using Big Data [30]. Tracking vehicles' locations using satellite navigation and sensors enables customers to know exactly where their shipment is and when it will be delivered. The vehicles' routes can be optimized by taking into account delivery addresses and data regarding road conditions, traffic jams, weather conditions, locations of gas stations, etc. Routing optimization saves a lot of fuel, which reduces financial cost and environmental impact. Fuel consumption can also be reduced by optimizing fuel input based on data from sensors that monitor the engine. Sensors can also monitor the state of the equipment and vehicle performance in real time. This helps predict errors and detect when maintenance is needed. Safety can also be improved with sensors that monitor vehicle speed, whether the driver is complying with the traffic laws and if the driver has been behind the wheel for too long [29].

US Xpress, an American logistics company, is an example of a company taking advantage of Big Data [29]. It has installed almost 1,000 sensors in each truck to monitor their locations, driving speed, petrol use, how often they break, if they are on idle for too long, when maintenance is required and even the drivers' capabilities. Hundreds of billions of data records generated help the company save over $\$ 6$ million a year.

It is presented in [25] how data regarding the fuel, speed, acceleration, etc. are collected from vehicles' sensors and GPS devices. They are then analyzed, which enables monitoring the driving behaviors to improve productivity, detecting negative driving patterns, determining which trucks are idling and wasting fuel, which trucks have the worst gas mileage and which drivers have the highest risk factor. The data flow is shown in Figure 2.

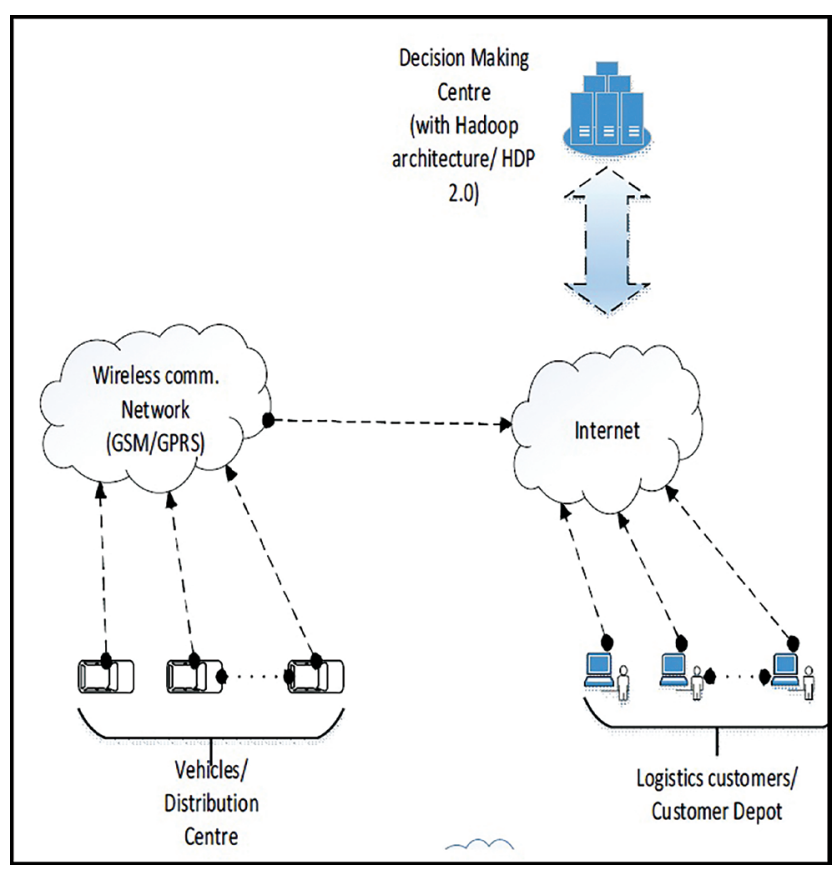

Figure 2 System data flow [25]

Slika 2. Tijek podataka sustava [25]

\section{BIG DATA IN THE MARITIME INDUSTRY / Primjena velikih skupova podataka u pomorskoj industriji}

4.1. Data sources and utilization strategies / Izvori podataka i strategije korištenja

There is a significant amount of data generated in navigation systems that consist of radar, electronic chart display and 
information system (ECDIS), auto-pilot system and other related sensors [22]. Moreover, special purpose vessels will require additional instrumentation relevant for their operations, such as wave radars, oil spill detectors and high accuracy inertial navigation sensors [24].

A subset of ship performance and navigation data, such as the vessel's unique identification number, position, course, speed and destination, are transferred by Automatic Identification System (AIS). Ships on international voyages of over 300 gross tonnage and all passenger ships are required to have AIS [28]. An AIS transponder exchanges data with other nearby ships, land based systems and satellites with the purpose of collision avoidance.

In addition, the Voyage Data Recorder (VDR), which is required on all passenger ships and other ships with gross tonnage of 3000 or more [27], connects to a number of electronic devices and stores the recorded information of each voyage as electronic data. Data items include the ship's position, speed, heading, audio from bridge microphones, communication audio, radar data, water depth, wind speed and direction, data from the alarms, hull openings status, watertight and fire door status, acceleration and hull stresses, the order and response of the engine and rudder. The volume of data is so large that, during long voyages, older data have to be overwritten to store new data. After the voyage is completed, the data are usually discarded. The main purpose of VDR is data analysis in case of an accident. However, instead of throwing this information away, it could be processed and effectively used with the help of Big Data techniques [15].

Perrera et al. [22] propose the data flow chart as presented in Figure 3. The data are collected from various onboard sensors and data acquisition systems, preprocessed and transmitted to shore based data centers where they are stored and analyzed. The result of the analysis is information that supports decisionmaking, for example to improve energy efficiency and system reliability.

According to [15], DNV-GL and Lloyd's Register Foundation (LRF), major worldwide classification societies, have already published their strategies on Big Data. DNV-GL points out six main areas in which Big Data is expected to be used: technical operation and maintenance, energy efficiency, safety performance, management and monitoring of accidents and environmental risks from shipping traffic, commercial operation and automation of ship operation. DNV-GL also suggests that the data may be owned and controlled not only by shipowners, but also ship builders, suppliers of components, the classification society, etc. LRF predicts that Big Data will enable condition-based maintenance, smart factories and autonomous machines. They intend to establish an infrastructure where data from various resources could be shared, certify the quality of data and control the rights and responsibilities of players in the market.

ClassNK is another classification society that has taken interest in Big Data. In fact, they have established the first shared Big Data platform in the maritime industry. The platform was built in 2016 by Fujitsu Limited. It collects machinery operational data from moving vessels, such as engine data, and enables ship operators, shipowners, shipyards, manufacturers and other maritime businesses to extract data as needed [10]. The ship's data are emailed to the onshore data center where they are converted and stored using IBM's secure cloud platform. Stored data can only be accessed strictly according to the requirements set by each company [16].

\subsection{Energy efficiency improvement / Unapređenje energetske učinkovitosti}

Ship performance and navigation information can be used to develop navigation strategies to improve ship energy efficiency [22]. Monitoring fuel consumption, various emissions, the use of lighting, heating and similar processes can result in insights that support decision-making.

In [23], data such as wind speed and direction, average draft, trim, main engine power, shaft speed and fuel consumption are analyzed and several higher fuel consumption trends under these parameter variations are noted. The optimal trim configuration is identified with respect to the fuel consumption rates. Applying strategies based on this information enables ships to meet energy efficiency and emission control standards. Along with environmental benefits, this is also significant for cost reduction.

\subsection{Safety improvement / Unapređenje sigurnosti}

Safety at sea can also benefit from implementing anomaly detection in marine operations. An overview of several machine learning techniques that can be used to detect anomalies from data gathered on vessel movement is presented in [20].

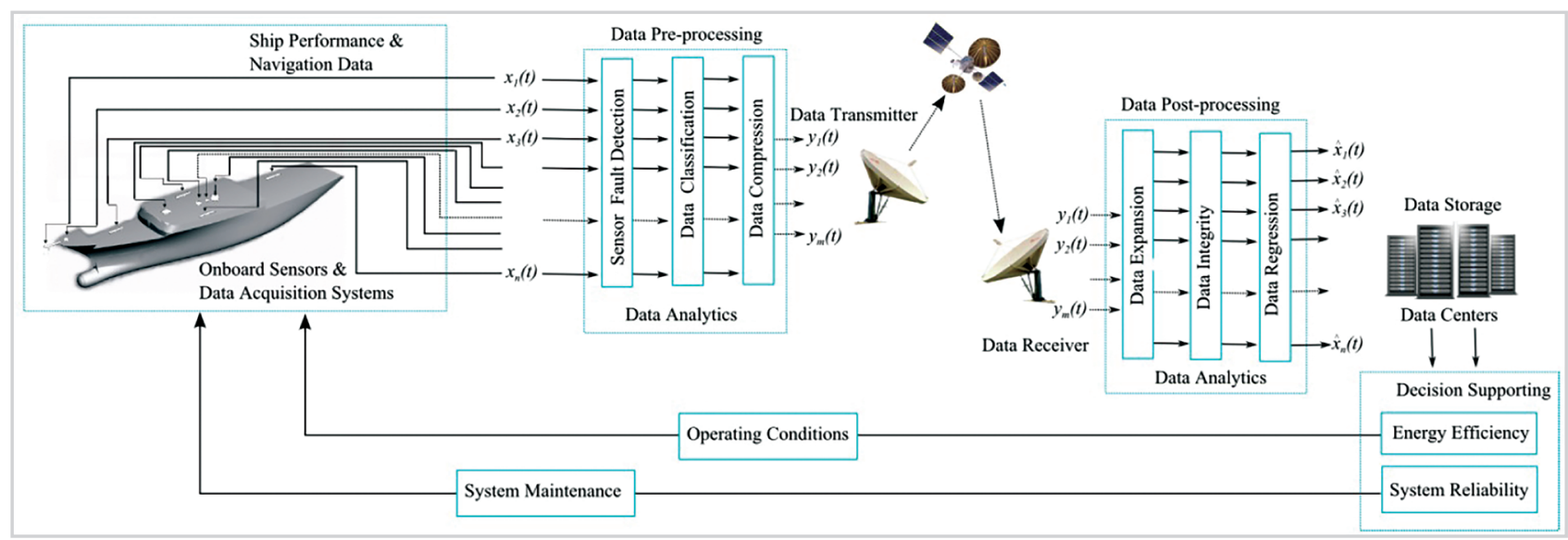

Figure 3 Data flow chart in ship performance and navigation information [22]

Slika 3. Dijagram toka podataka o performansama broda i navigacijskim informacijama [22] 


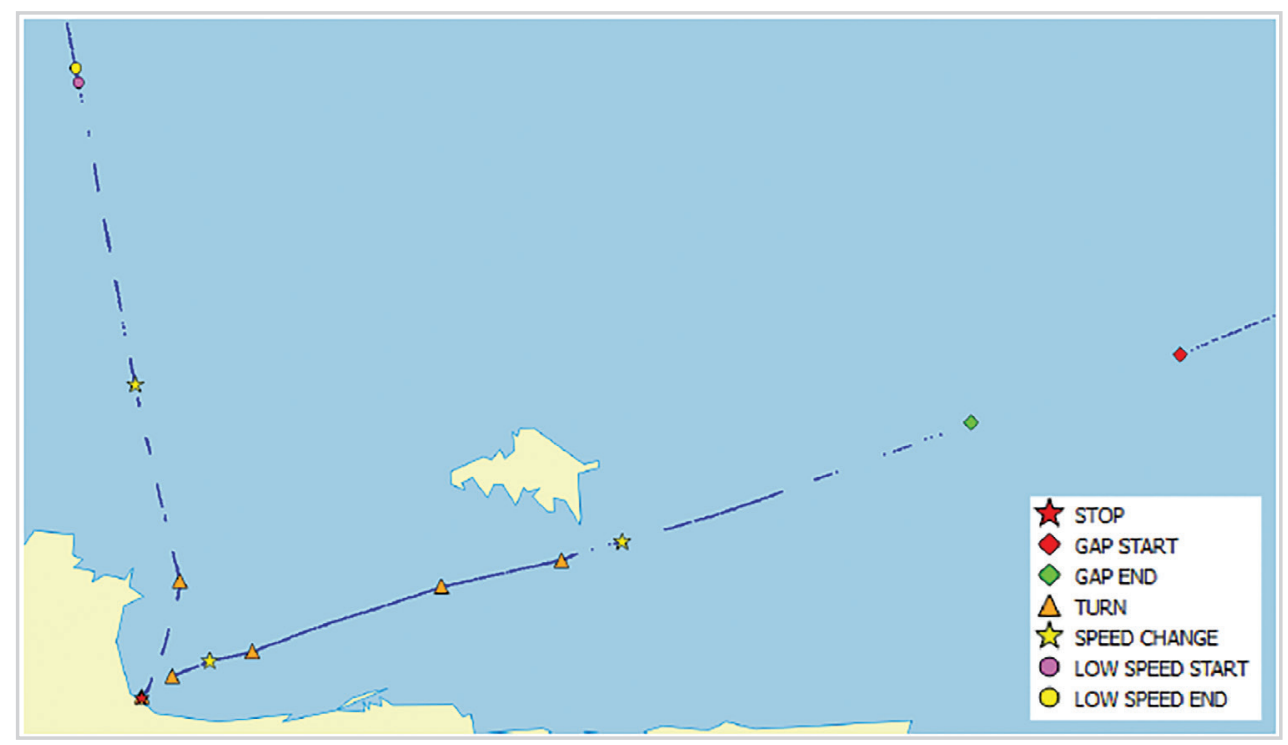

Figure 4 Critical points identified along a vessel trajectory [2] Slika 4. Kritičke točke koje su identificirane duž putanje broda [2]

In [4], an application of sensor-based anomaly detection in maritime transport is demonstrated. Sensor data, which include environmental and ship system information, are streamed from a ship to shore where they are analyzed through a Big Data analytics platform. Auto Associative Kernel Regression and the Sequential Probability Ratio Test technique are used to detect anomalies and trigger alarms so that appropriate action can be taken as soon as possible. Critical points identified along a vessel trajectory are shown in Figure 4.

A solution for real time monitoring of sensor data in a seaport infrastructure implemented in the Puerto de La Luz seaport in the Canary Islands is described in [9]. The system integrates data from AIS, various sensors and external sources, and provides a $3 \mathrm{D}$ map showing the ingoing and outgoing vessels, as well as the environmental conditions. It is equipped with an alert system which means that the port can easily identify issues and notify the vessels in order to prevent collisions, help the vessels avoid high waves, etc. Another example of Big Data used for anomaly detection is CMAXS, a maintenance system developed by ClassNK [16]. It uses real-time data collected from flow, pressure and temperature sensors on all engines and pumps. The data are analyzed for anomalies in order to detect potential damage as well as generate recommendations that help minimize downtime and reduce repairs.

In [6], the arrangement of Precaution Areas, whose purpose is minimizing the possibility of collisions, is optimized using AIS data. On the other hand, [1] shows how Big Data can be used to gain a better understanding of maritime activities, which is especially useful in remote areas such as the Arctic where shipping activity needs to be monitored to ensure sustainability and the information is otherwise difficult to access. It also discusses anomaly detection, such as detecting when a vessel deviates from the declared path, falsifies its AIS reports or turns off its AIS transponder to potentially engage in illegal activities. Figure 5 shows a vessel deviating from the known route (red dots), approaching a port and then returning to its declared route.

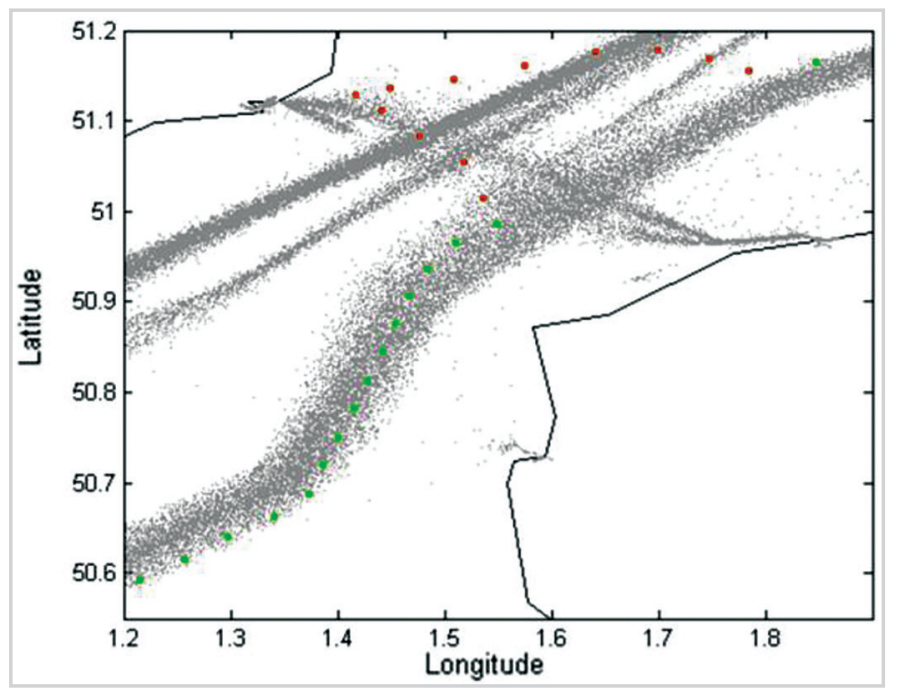

Figure 5 Local anomaly example [1]

Slika 5. Primjerak lokalne anomalije [1] 


\subsection{Logistics optimization / Optimizacija logistike}

When it comes to logistics and operational cost reduction, [8] states that Big Data can be used to minimize the time the ships spend anchored outside harbor waiting for an available slot, maximize the use of docks and synchronize the ship schedule with the logistics on shore.

Figure 6 shows vessel position prediction 48 hours in advance based on historical maritime traffic data. The last received AIS message is represented by the blue star and the destination port is represented by the green star. Accurate prediction of routes can be used to better estimate times of arrival in ports [1].

Brouer et al. [5] go into more detail, showing how operational data can be used to build predictive models that can then provide input for the decision-making process. Optimization within maritime logistics is complicated due to the size of the network that carriers operate and the uncertainty caused by delays, fluctuations in demand, no-show cargo, etc. Machine learning techniques can provide predictions of delays due to bad weather or congestion, required maintenance, estimates of future demand and oil prices, but complex decisions must be made to adjust the transportation network to the new situation. The paper shows how methods such as mathematical programming can help make the best choice in the examples of liner shipping network design, empty container repositioning, container vessel stowage plans, bunker purchasing at minimal cost and schedule recovery in case of disruptions. Route optimization is shown in Figure 7.

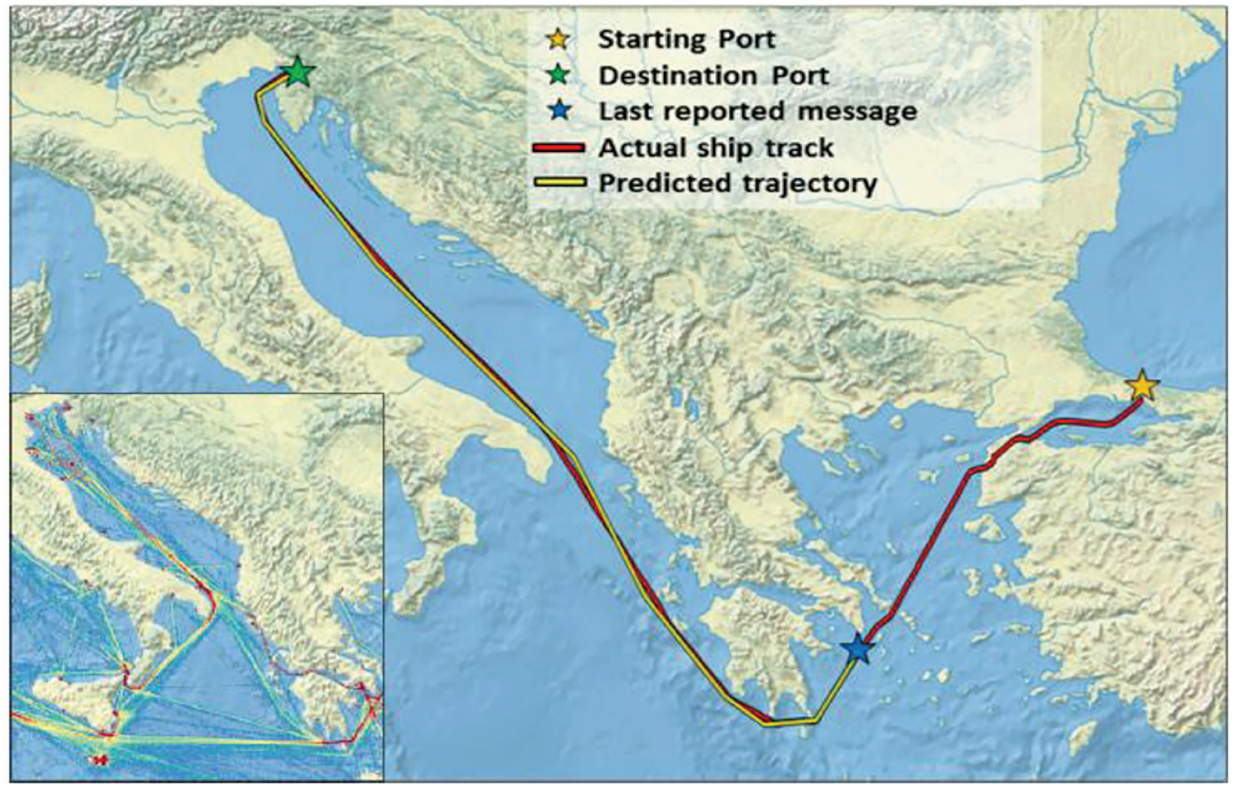

Figure 6 Prediction of a vessel track [1] Slika 6. Predviđanje putanje broda [1]

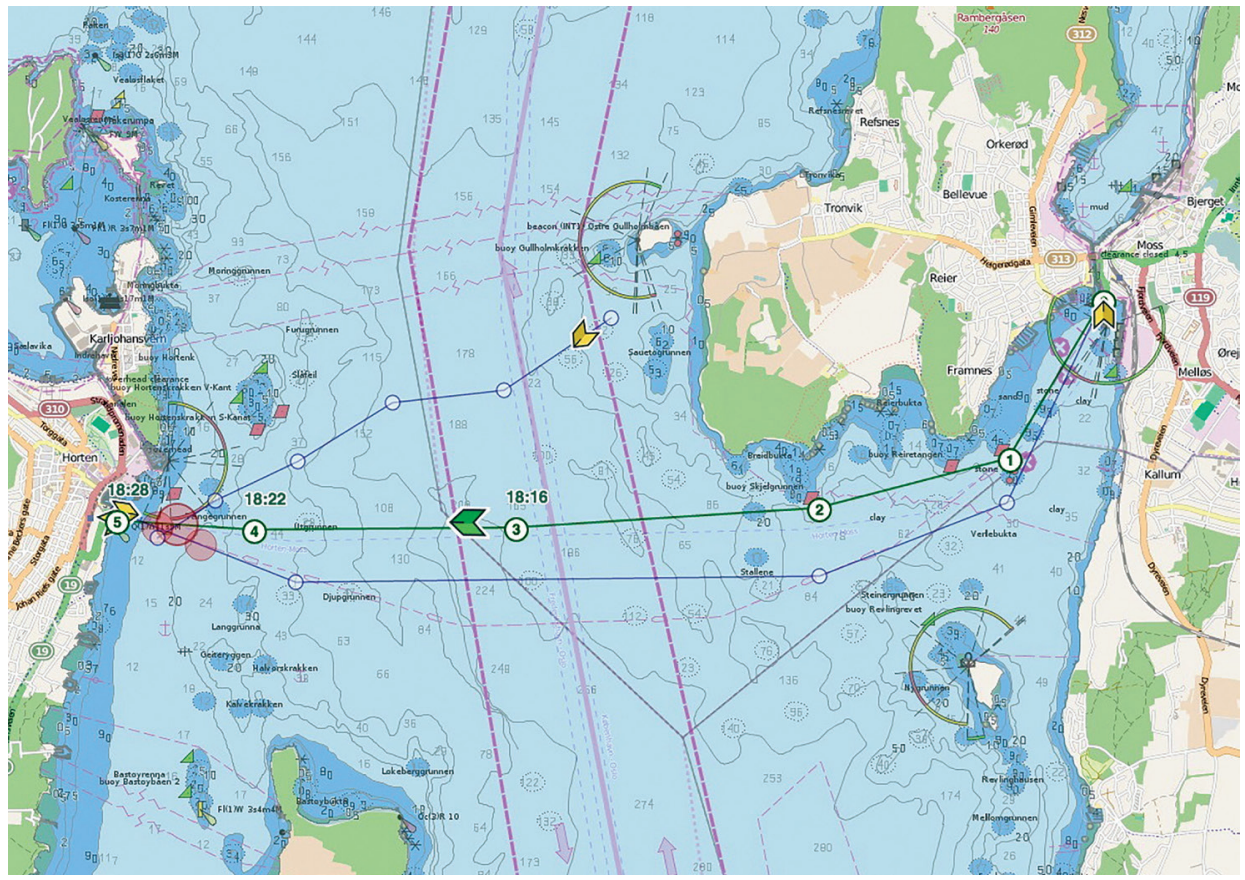

Figure 7 Route optimization [31]

Slika 7. Optimizacija rute [31] 


\section{CONSTRAINTS AND CHALLENGES / Ograničenja i izazovi}

In general, systems involving Big Data face challenges related to data quality and quantity. Ship performance and navigation data collected by sensors and data acquisition systems create both quantity and quality issues. Data may be erroneous, due to sensor faults or accidental mistakes made during manual entry. Sometimes, the errors are willful, when operators have economic interests in reporting misleading data or in an attempt to disguise illegal activity. One possible solution is using automated data entry, which may be too costly. Another solution is extensive validity check [24].

In order to minimize errors, the data have to be cleaned before being analyzed. Data cleaning includes tasks such as anomaly detection, conflicting values detection and incomplete data filling. However, [30] points out that many data cleaning strategies are not suitable for Big Data and that noise and extreme values rejected in this process may in fact contain useful information. Another issue is context dependency, meaning that, in some cases, additional and possibly unavailable information is needed to interpret the data correctly, such as the exact location of the sensor [24].

Data quantity results in issues regarding storage and transfer of data between ship and shore. There are limitations in maximum available bandwidth and costs of transmissions via high sea satellite communication, at least in some areas [24]. Using a subset of the large-scale data set, statistical data analysis and machine intelligence techniques in order to overcome data quantity issues are proposed in [22]. Koga [15] states that there is a need for equipment with more capacity and capability, and expresses the need for standardization of data in order to make data integration easier.

Furthermore, [21] names model uncertainty as one of the main issues and states that data driven models may fail due to quality and quantity issues and proposes to use domain knowledge to improve the accuracy.

Another major challenge is the shortage of specialists of data-related engineering, especially in the maritime industry which is not originally information-intensive [15]. In a survey released by Sea Asia 2017, the majority of maritime leaders agreed that a severe skills shortage is preventing the industry from effectively harnessing Big Data [19].

In all disciplines, Big Data raises serious ethical and privacy issues, and a legislative framework that will dictate the boundaries of using data is missing [30]. DNV-GL considers that well-established governance of data is one of the fundamental issues. It is pointed out in [15] that, if different kinds of data are concerned, the stakeholders who should have property rights may differ. The paper also acknowledges the importance of making sure that the rights of certain data aren't monopolized.

Any physical connection into networks or systems can be vulnerable to hostile attacks and reports sent from ship to shore or vice versa can be intercepted and tampered with [24]. According to [15], LRF points out that the unlawful control of device/machine and abusive insertion, update and deletion of data are risks of Big Data security. Systems involving Big Data have to be secure enough to make a criminal access unsuccessful and, in the legislative aspect, illegal activities need to be defined and prohibited [15].

\section{CONCLUSION / Zaključak}

Big Data techniques can be used to monitor vessels in real time and analyze ship performance and navigation data collected from onboard sensors and data acquisition systems. The insights gained enable development of strategies regarding optimal logistics network design and energy efficiency. Along with cost reduction and environmental benefits, safety at sea can also be improved. Anomaly detection makes it possible to identify issues in real time so that they can be resolved as soon as possible.

However, dealing with Big Data means facing issues regarding data quantity and quality. The maritime industry in particular lacks data-related experts. In addition, there are security and privacy challenges that require setting up a legislative framework that will dictate the governance of data.

The maritime industry could benefit greatly from utilizing Big Data, but a number of challenges need to be overcome before it is possible to use it to its full potential.

\section{REFERENCES / Literatura}

[1] Alessandrini, A. et al., 2016, “Mining Vessel Tracking Data for Maritime Domain Applications", 2016 IEEE 16th International Conference on Data Mining Workshops (ICDMW), pp. 361-367. https://doi.org/10.1109/ICDMW.2016.0058

[2] Alevizos, E., Artikis, A., Patroumpas, K., Vodas, M., Theodoridis, Y., Pelekis, N., 2015, "How not to drown in a sea of information: An event recognition approach", 2015 IEEE International Conference on Big Data (Big Data), pp. 984-990. https://doi.org/10.1109/BigData.2015.7363849

[3] Ben Ayed, A., Ben Halima, M., Alimi, A. M., 2015, "Big Data Analytics for Logistics and Transportation", 4th IEEE International Conference on Advanced logistics and Transport, pp. 311-316. https://doi.org/10.1109/ICAdLT.2015.7136630

[4] Brandsæter, A., Manno, G., Vanem, E., Glad, I. K., 2016,"An application of sensor-based anomaly detection in the maritime industry", IEEE International Conference on Prognostics and Health Management (ICPHM), pp. 1-8. https://doi.org/10.1109/ICPHM.2016.7811910, https://doi.org/10.1109/ ICPHM.2016.7754713

[5] Brouer, B. D., Karsten, C. V., Pisinger, D., 2016, "Big Data Optimization in Maritime Logistics", Big Data Optimization: Recent Developments and Challenges, pp. 319-344. https://doi.org/10.1007/978-3-319-30265-2_14

[6] Chen, J., Lu, F., Li, M., Huang, P., Liu, X., Mei, Q., 2016, "Optimization on Arrangement of Precaution Areas Serving for Ships' Routeing in the Taiwan Strait Based on Massive AIS Data", DMBD 2016: Data Mining and Big Data, pp. 123-133. https://doi.org/10.1007/978-3-319-40973-3_12

[7] De Mauro, A., Greco, M., Grimaldi, M., 2014, "What is Big Data? A Consensual Definition and a Review of Key Research Topics", 4th International Conference on Integrated Information, pp. 97-104.

[8] Domínguez, A. G., 2014, “'Smart Ships': Smart Mobile Applications, Cloud and Bigdata on Marine Traffic for Increased Safety and Optimized Costs Operations", 2014 2nd International Conference on Artificial Intelligence, Modelling and Simulation, pp. 303-308. https://doi.org/10.1109/AIMS.2014.39

[9] Fernández, P. et al., 2017, “Web-Based GIS Through a Big Data Open Source Computer Architecture for Real Time Monitoring Sensors of a Seaport", The Rise of Big Spatial Data, pp. 41-53. https://doi.org/10.1007/978-3-319-451237_4

[10] Fujitsu Limited, 2016, "A shared maritime platform for use by maritime businesses, which aggregates ship and marine weather data". Available: http://www.fujitsu.com/global/about/resources/news/pressreleases/2016/0506-01.html(14.5.2017.)

[11] Gandomi, A., Haider, M., 2015, "Beyond the hype: Big data concepts, methods, and analytics", International Journal of Information Management, 35, pp. 137144. https://doi.org/10.1016/j.ijinfomgt.2014.10.007

[12] Gantz, J., Reinsel, D., 2012, "The Digital Universe in 2020: Big Data, Bigge Digital Shadows, and Biggest Growth in the Far East", IDC IView. Available: https://www.emc.com/collateral/analyst-reports/idc-the-digital-universein-2020.pdf (12.5.2017.)

[13] International Maritime Organization, 2012, "IMO's contribution to sustainable maritime development". Available: http://www.imo.org/en/OurWork/ TechnicalCooperation/Documents/Brochure/English.pdf (28.6.2017.)

[14] Jain, V. K., 2017, “Big Data and Hadoop", Khanna Publishing, New Delhi.

[15] Koga, S., 2015, "Major challenges and solutions for utilizing big data in the maritime industry", Thesis MSc World Maritime University (Malmö, Sweden). 
[16] Kurashiki, T., 2016, "Maritime Big Data Solutions by ClassNK". Available: http://www.mpa.gov.sg/web/wcm/connect/www/c3f96729-2bac4c77-9cad-e61954a83e2d/Presentation+-+Toshio+Kurashiki. pdf?MOD=AJPERES(14.5.2017.)

[17] Lohr, S., 2012, "The Age of Big Data", The New York Times. Available: http:// www.nytimes.com/2012/02/12/sunday-review/big-datas-impact-in-theworld.html(12.5.2017.)

[18] Nemschoff, M., 2014, "Why the Transportation Industry is Getting on Board with Big Data \& Hadoop". Available: https://mapr.com/blog/whytransportation-industry-getting-board-big-data-hadoop/(12.5.2017.)

[19] Network Adria, 2017, "Severe skills shortage preventing maritime industry from harnessing Big Data". Available: https://www.networksasia.net/article/ severe-skills-shortage-preventing-maritime-industry-harnessing-bigdata.1487773464 (27.6.2017.)

[20] Obradović, I., Miličević, M., Žubrinić, K., 2014, “Machine Learning Approaches to Maritime Anomaly Detection", International Journal of Maritime Science \& Technology "Our Sea", 61 (5-6), pp. 96-101.

[21] Perera, L. P., 2017, "Handling Big Data in Ship Performance and Navigation Monitoring", Smart Ship Technology, pp. 89-97.

[22] Perera, L. P., Mo, B., 2016, “Machine Intelligence for Energy Efficient Ships: A Big Data Solution", 3rd International Conference on Maritime Technology and Engineering (MARTECH 2016), pp. 143-150. https://doi.org/10.1201/b21890-21

[23] Perera, L. P., Mo, B., Kristjánsson, L. A., 2015, “Identification of Optimal Trim Configurations to improve Energy Efficiency in Ships", 9th IFAC Con-ference on Manoeuvring and Control of Marine Craft (MCMC 2015), pp. 267-272.
[24] Rødseth, Ø. J., Perera, L. P.; Mo, B., 2016, "Big data in shipping - Challenges and Opportunities", Proceedings of the 15th International Conference on Computer Applications and Information Technology in the Maritime Industries (COMPIT 2016), pp. 361-373.

[25] Sivan, A. P., Johns, J., Venugopal, J., 2014, “Big Data Intelligence in Logistics Based On Hadoop And Map Reduce", IJIRSET, 3, pp. 2634-2640.

[26] Snijders, C., Matzat, U., Reips, U.-D., 2012, "'Big Data': Big Gaps of Knowledge in the Field of Internet Science", International Journal of Internet Science, 7(1), pp. 1-5.

[27] SOLAS, Guidance on Chapter V - Safety of Navigation (Revision), 2007, Annex 10 - Voyage Data Recorders (VDRs). Available: http://solasv.mcga.gov.uk/ annexes/Annex10.htm (27.6.2017.)

[28] SOLAS, Guidance on Chapter V - Safety of Navigation (Revision), 2007, Annex 17 - Automatic Identification Systems (AIS). Available: http://solasv.mcga.gov. uk/annexes/Annex17.htm (27.6.2017.)

[29] Van Rijmenam, M., 2014, "Think Bigger: Developing a Successful Big Data Strategy for Your Business", Amacom New York, NY.

[30] Vlahogianni, E. I., 2015, "Computational Intelligence and Optimization for Transportation Big Data: Challenges and Opportunities", Computational Methods in Applied Sciences, 38, pp. 107-128.https://doi.org/10.1007/978-3319-18320-6_7

[31] Wojnarowicz, K., 2015, "Industrial Internet of Things in the Maritime Industry". Available: http://blog.blackducksoftware.com/industrial-internet-of-thingsin-the-maritime-industry/ (28.6.2017.) 